\title{
THE IMPACT OF CREDIBILITY OF INFLUENCERS RECOMMENDATIONS ON SOCIAL MEDIA ON CONSUMERS BEHAVIOR TOWARDS BRANDS
}

\section{UTJECAJ VJERODOSTOJNOSTI PREPORUKA INFLUENCERA NA DRUŠTVENIM MREŽAMA NA PONAŠANJE POTROŠAČA PREMA MARKAMA}

\author{
Piotr Kwiatek, Radoslav Baltezarević, Stavros Papakonstantinidis \\ American University of the Middle East, Kuwait; Cyprus International Institute of Management, Cyprus; American \\ University of the Middle East, Kuwait \\ Američko sveučilište na Bliskom istoku, Kuvajt; Ciparski međunarodni institut za menadžment, Cipar; Američko sveučilište \\ na Bliskom istoku, Kuvajt
}

\section{Abstract}

Companies are becoming increasingly aware of the importance and opportunities provided by social media in order to communicate faster and more efficiently with their consumers. In order to convey the message about the value of their brands to their target market, organizations hire influential people who are considered to be the creators of public opinion in a virtual environment. Nowadays, social media are crowded with micro and macro influencers, or at least those who present themselves as such. Their main job is to represent and recommend brands to other users (their followers) and thus influence consumer attitudes about brands and possibly strengthen their purchasing decisions. Very often, influencers on social media are hired by companies to promote their brands for a fee. In order to have more control over their communication activities, companies provide them, in advance, with the content they want to be conveyed to consumers, but also the time frame when the message should be launched. In this way, organizations try to reduce the risk of turning electronic word-of-mouth (EWOM) communication into a negative one. In order for consumers to trust the recommendations of influencers on
Sažetak

Tvrtke sve više postaju svjesne važnosti i mogućnosti koje pružaju društvene mreže kako bi brže i učinkovitije komunicirale sa svojim potrošačima. Također, vrlo često, kako bi na svoje ciljno tržište prenijele poruku o vrijednosti svojih marki, organizacije angažiraju utjecajne ljude koji se smatraju tvorcima javnog mnijenja u virtualnom okruženju. Danas su društveni mediji pretrpani mikro i makro influencerima ili barem onima koji se predstavljaju kao takvi. Njihov je glavni posao predstavljati i preporučivati marke drugim korisnicima (njihovim sljedbenicima) i na taj način utjecati na stavove potrošača o robnim markama i možda ojačati njihove odluke o kupnji. Vrlo često tvrtke angažiraju influencere na društvenim mrežama kako bi uz naknadu promovirali svoje marke. Kako bi imale veću kontrolu nad svojim komunikacijskim aktivnostima, tvrtke im unaprijed dostavljaju sadržaj koji žele prenijeti potrošačima, ali i vremenski okvir kada bi poruka trebala biti pokrenuta. Na taj način organizacije pokušavaju smanjiti rizik pretvaranja elektroničke komunikacije usmenom predajom (EWOM) u negativnu. Da bi potrošači mogli vjerovati preporukama influencera na društvenim mrežama, ti ljudi moraju imati značajnu 
social media, these people need to have significant expertise in a certain area, charisma and respect from other users, so that their credibility affects the value of content and recommendations they place in the online environment. The aim of this paper is to present the attitudes of respondents who use social media websites about the impact of the credibility of influencers' recommendations on social media, and their opinion on whether and in what way their credibility influences consumer attitudes towards brands.

\section{Introduction}

In the field of information technologies innovations are taking place very fast and are being introduced through social media and networking websites. LinkedIn, Facebook, Twitter, etc., are providing new social interaction patterns of communication/1/. Social media mediates the creation of communities and networks by encouraging participation and interest. It is a term used for internet tools and websites that offer a chance to their users to interact with one another through information, opinion, interest and sharing /2/. Alexandrov, Lilly \& Babakus /3/, explored the impact of social and personal needs on word-ofmouth communication, placing particular emphasis on brand-specific communication. They found that word-of-mouth communication arise from the intention of the consumers to engage in social interaction to meet their needs. They also found that the intent of the creators of positive word-of-mouth communication is to enhance their own image. Some previous findings have shown that WOM recommendations are more effective compared to other marketing strategies $/ 4 /$, because of the higher level of credibility /5/. Online review is becoming an important means of marketing communication as many consumers search for it as the first step of an online purchase /6/.

Positive electronic word-of-mouth (EWOM), as a free form of advertising, can help organizations by strengthening their brand or driving sales /7/. On the other hand, Hornik et al. /8/, argue that negative communication has a greater impact than positive. Henning et al. /9/, stručnost u određenom području, karizmu i poštovanje drugih korisnika, tako da njihova vjerodostojnost utječe na vrijednost sadržaja i preporuka koje daju u internetskom okruženju. Cilj ovog rada je predstaviti stavove ispitanika koji koriste web stranice društvenih mreža o utjecaju vjerodostojnosti preporuka influencera na društvenim mrežama te njihovo mišljenje o tome utječe li i na koji način njihova vjerodostojnost na stavove potrošača prema robnim markama.

added that negative reviews on social media have the effect of discouraging potential consumers who have looked at the messages on the website, resulting in reducing their sales potential in the future.

Uzunoğlu \& Kip /10/, noted that social media influencers through their images, messages and recommendations, can shape attitudes, opinions and, finally, actions of consumers and strongly influence their final purchase decisions. Langer et al. /11/ stated that some studies consider social media influencers as social leaders, who actually, with their great social capital, set standards and lead the internet community proportionately to its values and the behavior of its members. In most cases, recommendations and electronic word-of-mouth (EWOM) are built on credibility and trust /12/. Influencers "who are perceived to be attractive are more likely to lead the purchase intent" /13/. According to Pornpitakpan /68/, credibility is one of the main factors in persuasion. Lee \& Koo /14/ added, if the consumer perceives recommendations as not authentic and biased, in that case the level of credibility decreases.

\section{Research objectives}

This paper discusses the influence of credibility of influencers recommendations on social media on consumers behavior toward brands. The aim of this paper is to present the results of the research aimed at establishing the correlation between credibility of influencer recommendations in the digital environment, primarily on social networks, and the changes that these recommendations may have on 
consumers perception towards brands and the consequences of these influences on their purchasing decisions.

In relation to the research of the available literature, we have constructed the following hypotheses:

H1 If consumers are searching for the brand recommendation, then they will have a tendency to trust more EWOM than WOM.

$\mathrm{H} 2$ If consumers are searching for online recommendation, when seeking for information about brands, then they will perceive Macro-influencers as more credible sources than Micro-influencers.

H3 If consumers, when seeking for online information, read a negative review, that can cause a negative attitude toward the brand, and reduce the sales potential in the future.

\section{Sample and Data Collection}

This research was carried out through a specially prepared questionnaire with closed-type questions sent to 350 electronic addresses of students and employees at a private university based in Belgrade (Republic of Serbia). A total of 326 fully filled questionnaires were selected for further research. The IBM Statistical Package for Social Science (IBM SPSS v22) was used to analyse the data collected from the survey. Data were analysed using descriptive statistic, chi-square test and measures of association.

The questionnaire was composed of two parts. In the first part, questions were posed regarding the demographic profile of the respondents (gender, age and level of education). The second part of the questionnaire asked the respondents to answer closed-ended questions related to their behaviour in online environment and their perception of SMI credibility, with offered answers in reference to the Likert five-point scale of attitudes, anchored: 1 . Strongly disagree, 2. Disagree, 3. Neither agree nor disagree, 4. Agree 5. Strongly agree.

Data were collected in the period from August 2019 to September 2019.

\section{Results and Discussion}

To test the hypothesis in this paper, we made a list of six variables and tested the Internal reliability of the thus formed scale using the Kronbah (Cronbach) alpha analysis.

Demographic Profile of the Respondents $(\mathrm{N}=326)$

\begin{tabular}{llcc}
\hline Demographic & $\mathrm{N}$ & $\%$ \\
\hline Gender & & & \\
& Male & 156 & 47.9 \\
& Female & 170 & 52.1 \\
Age & & & \\
& $18-25$ & 138 & 42.3 \\
& $26-35$ & 81 & 24.8 \\
& $36-45$ & 58 & 17.8 \\
& $46-55$ & 36 & 11.0 \\
& $56-65$ & 13 & 4.0
\end{tabular}

Education

$\begin{array}{lrr}\text { High school } & 67 & 20.6 \\ \text { Bachelor } & 127 & 39.0 \\ \text { Master } & 54 & 16.6 \\ \text { Doctorate } & 78 & 23.9\end{array}$

\footnotetext{
The internal consistency reliabilities using the Cronbach $\alpha$ coefficient for all items RQ1-RQ10. $\alpha=.939$ shows that the scale is well placed because of a value $\alpha>0.07$, which means that the scale is reliable because higher correlation means greater reliability (Bland J, Altman D. Statistics notes: Cronbach's alpha. BMJ. 1997; Vol 314, p. 572).
} 
H1 If consumers are searching for the brand recommendation, then they will have a tendency to trust more EWOM than WOM.
RQ1 Do you agree with the statement that when searching for the brand recommendation, consumers tend to trust EWOM?

RQ2 Do you agree with the statement that when searching for the brand recommendation, consumers tend to trust WOM?

Table 1. (RQ1) The attitude of the respondents regarding the claim that when searching for the brand recommendation, consumers tend to trust EWOM

\begin{tabular}{lll} 
RQ1 & & \\
\hline \hline & Frequency & Percent \\
Strongly disagree & 31 & 9.5 \\
Disagree & 34 & 10.4 \\
Neither agree nor disagree & 70 & 21.5 \\
Agree & 152 & 46.6 \\
Strongly agree & 39 & 12.0 \\
Total & 326 & 100.0 \\
\hline \hline
\end{tabular}

$\mathrm{M}=3.41 ; \mathrm{SD}=1.1244 ; \mathrm{Mdn}=4$

Table 1. indicates that the highest percentage of respondents agree with the claim (46.6\%).
Table 2. (RQ2). The attitude of the respondents regarding the claim that when searching for the brand recommendation, consumers tend to trust WOM

\begin{tabular}{lll} 
RQ2 & & \\
\hline \hline & Frequency & Percent \\
\hline Strongly disagree & 18 & 5.5 \\
Disagree & 42 & 12.9 \\
Neither agree nor disagree & 79 & 24.2 \\
Agree & 158 & 48.5 \\
Strongly agree & 29 & 8.9 \\
Total & 326 & 100.0 \\
\hline \hline
\end{tabular}

$\mathrm{M}=3.42 ; \mathrm{SD}=1.007 ; \mathrm{Mdn}=4$

Table 2. indicates that the highest percentage of respondents agree with the claim (48.5\%).

A chi-square test was performed to verify the existence of relationship between attitude towards the claim when searching for the brand recommendation, consumers tend to trust EWOM and the attitude towards the claim that when searching for the brand recommendation, consumers tend to trust WOM. The relationship between these variables is statistically significant, $\chi^{2}(12,1)=106.067, p<0.01$. Pearsons correlation $\mathrm{r}=.574$ indicates positive high correlation. The first hypothesis is confirmed.

H2 If consumers are searching for online recommendation, when seeking for information about brands, then they will perceive Macroinfluencers as more credible sources than Microinfluencers. 
Piotr Kwiatek, Radoslav Baltezarević, Stavros Papakonstantinidis: THE IMPACT OF CREDIBILITY OF INFLUENCERS RECOMMENDATIONS ON SOCIAL MEDIA ON CONSUMERS BEHAVIOR TOWARDS BRANDS Informatol. 54, 2021., 3-4

185

RQ3 Do you agree with the statement that consumers are searching for online recommendation when seeking for information about brands?
RQ4 Do you agree with the statement that when searching for online recommendation, consumers perceive Macro-influencers as more credible sources than Micro-influencers?

Table 3. (RQ3). The attitude of the respondents regarding the claim that consumers are searching for online recommendation when seeking for information about brands

\begin{tabular}{llll} 
RQ3 & & & \\
\hline \hline & & Frequency & Percent \\
\hline Strongly disagree & 13 & 4.0 \\
Disagree & 78 & 23.9 \\
Neither agree nor disagree & 73 & 22.4 \\
Agree & 146 & 44.8 \\
Strongly agree & 16 & 4.9 \\
Total & 326 & 100.0 \\
\hline \hline
\end{tabular}

$\mathrm{M}=3.23 ; \mathrm{SD}=.997 ; \mathrm{Mdn}=4$.

Table 3. indicates that the highest percentage of respondents agree with the claim (44.8\%).

Table 4. (RQ4). The attitude of the respondents regarding the claim that when searching for online recommendation, consumers perceive Macro-influencers as more credible sources than Micro-influencers

\begin{tabular}{llll} 
RQ4 & & & \\
\hline \hline & Strongly disagree & 30 & 9.2 \\
& Disagree & 36 & 11.0 \\
\multirow{4}{*}{ Valid } & Neither agree nor disagree & 80 & 24.5 \\
& Agree & 148 & 45.4 \\
& Strongly agree & 32 & 9.8 \\
& Total & 326 & 100.0 \\
\hline \hline
\end{tabular}

$\mathrm{M}=3.36 ; \mathrm{SD}=1.096 ; \mathrm{Mdn}=4$

Table 4. indicates that the highest percentage of respondents agree with the claim $(45.4 \%)$.

A chi-square test was performed to verify the existence of relationship between attitudes towards the claim that consumers are searching for online recommendation when seeking for information about brands and the attitude towards the claim that when searching for online recommendation, consumers perceive Macroinfluencers as more credible sources than Micro-influencers. The relationship between these variables is statistically significant, $\chi^{2}(16,1)=379.901, p<0.01$. Pearsons` correlation $\mathrm{r}=.517$ indicates positive high correlation. The second hypothesis is confirmed.

H3 If consumers, when seeking for online information, read a negative review, that can cause a negative attitude toward the brand, and reduce the sales potential in the future.

RQ5. Do you agree with the statement that a negative online review can cause a negative consumer attitude toward brand?

Coden: IORME7 
RQ6. Do you agree with the statement that a negative online review can reduce the sales potential in the future?

Table 5. (RQ5). The attitude of the respondents regarding the claim that a negative online review can cause a negative consumer attitude toward brand?

\begin{tabular}{lll} 
RQ5 & & \\
\hline \hline & Frequency & Percent \\
\hline Strongly disagree & 21 & 6.4 \\
Disagree & 39 & 12.0 \\
Neither agree nor disagree & 78 & 23.9 \\
Agree & 154 & 47.2 \\
Strongly agree & 34 & 10.4 \\
Total & 326 & 100.0 \\
\hline \hline
\end{tabular}

$\mathrm{M}=3.43 ; \mathrm{SD}=1.041 ; \mathrm{Mdn}=4$

Table 5. indicates that the highest percentage of respondents agree with the claim (47.2\%).

Table 6. (RQ10). The attitude of the respondents regarding the claim that a negative online review can reduce the sales potential in the future.

\begin{tabular}{|c|c|c|}
\hline & Frequency & Percent \\
\hline Strongly disagree & 31 & 9.5 \\
\hline Disagree & 34 & 10.4 \\
\hline Neither agree nor disagree & 60 & 18.4 \\
\hline Agree & 152 & 46.6 \\
\hline Strongly agree & 49 & 15.0 \\
\hline Total & 326 & 100.0 \\
\hline
\end{tabular}

$\mathrm{M}=3.47 ; \mathrm{SD}=1.155 ; \mathrm{Mdn}=4$

Table 6. indicates that the highest percentage of respondents agree with the claim $(46.6 \%)$.

A chi-square test was performed to verify the existence of relationship between attitudes towards the claim that consumers consider as reliable sources of information online reviews posted by other consumers and attitude towards the claim that consumers consider online reviews posted by other consumers, as more reliable sources of information, than reviews posted by the company. The relationship between these variables is statistically significant, $\chi^{2}(16,1)=487.369, p<0.01$. Pearsons' correlation $\mathrm{r}=.559$ indicates high moderate correlation. The third hypothesis is confirmed.

\section{Social media - definition and conceptualization}

Social media refers to technology that is computer-mediated, facilitating the growth and sharing of awareness, ideas, interests, information, and other methods of expression through virtual communities and social networks /15/. According to Kapoor et al. /16/ social media a set of information technologies which facilitate networking and interactions. Carr \& Hayes /17/, stated that Social media can be defined as "Internet-based, disentrained, 
and persistent channels of mass personal communication facilitating perceptions of interactions among users, deriving value primarily from user-generated content". Social media may be defined as web sites that are based on web 2.0 technologies, that enable community formation, deeper social interaction, and preparation in cooperation projects/18/.

The contents created by social media users (posts, digital photos, comments, video sharing, etc.) represent the lifeblood of social media sites and social networking $/ \mathbf{1 9 /}$. Users of social media can see or read online posts, that are self-published of their friends, without direct interaction with them $/ \mathbf{2 0} /$. The biggest motive for users to be active on social networks is the need to get more information about anything, through content transmitted digitally and shared at high speed /21/. Studies have shown that consumers visit social networking sites to stay up-to-date with specific brands and their promotional campaigns /22/.

The ability of social media to automatically segment the market is one of the reasons why they are so effective. Marketers are using social media to promote products and services. The advent of social networking sites such as Twitter and Facebook opened the door for marketers to reach a million new opportunities /23/. Social networks enable consumers to share text, images, video and audio information with one another $/ 24 /$.

\section{Word-of-mouth communication (WOM) vs Electronic word-of-mouth communication (EWOM)}

Word-of-mouth communication (WOM) is based on the premise that people like to talk about products, services, relationships, not only verbally, but on social networks, through various forums, or blogs on the web. A commitment to this type of communication is an attempt by companies to enable people to start a conversation easily on topics related to brands and focuses on companies' activities to encourage consumers to receive positive recommendations from them /25/. Henning et al. /26/, ISSN 1330-0067 pointed out that word-of-mouth communication is defined as a positive or negative statement by consumers about a product or company that is available to a large number of people and organizations using the Internet. Westbrook /27/, defined WOM as informal communications directed to other consumers about the use, ownership or characteristics of certain products and services and/or their vendors. Emanuel Rosen /28/ stated that WOM refers to communication between two people about criticism of a brand, product, service or company at any time.

Word-of-mouth communication is described as verbal communication (positive or negative), between groups such as product suppliers, current or potential consumers, independent professionals, friends and family $/ 29 /$. This type of communication is often cited as the most effective form of communication for influencing consumers and plays an important role in shaping their attitudes and buying behavior /30/. Katz \& Lazarsfeld /31/, found that this type of communication initiated to influence consumers, at the stage of brand change, is seven times more effective than advertising in magazines and newspapers, four times more effective than personal selling and twice more effective than radio advertising. Garnefeld et al. /32/ added that, WOM is an extremely effective for acquiring new consumers, and it does not burden the company financially. This is because of the fact, that in this kind of communication, consumers communicate with each other. Goyette et al. /33/ believe that word-of-mouth communication is probably the oldest means of exchanging views on various products and services. According to attribution theory, if the sender is trusted to provide reliable information and genuinely helps recipients to experience optimal benefit, the recipients will respond positively and in accordance with the recommendations offered to them /34/. However, if recipients believe that the sender misuses word-of-mouth communication, just to take revenge on the company because of their personal dissatisfaction, which is a common motivation for negative WOMs, recipients will less likely act according to received information 
/35/. A study conducted by Assael /36/, confirmed previous research findings, which noted that negative WOM influences consumer attitudes more than positive. Day /37/ estimated WOM to be nine times more effective than advertising in converting negative or neutral consumer attitudes into positive ones. Morin /38/ has shown that other people's recommendations are three times more effective, compared to advertisements, in encouraging purchases. Compared to traditional word-of-mouth communication (WOM), electronic word-of-mouth communication (EWOM) is less personalized, mostly anonymous, and takes place among people who are in weak relationships. EWOM is considered a more powerful tool, because it has more significant reach, credibility, and is publicly available /39/. EWOM is defined as informal communication between consumers, using internet-based technology, which refers to the uses or characteristics of certain goods, services or their suppliers /40/. EWOM can be explained as a communication directed to consumers on the Internet, along with product reviews and recommendations /41/. The development and dissemination of the Internet have expanded the ability of consumers to gather information about products and services, including comments and reviews from other consumers posted online. The Internet has, also, with the inclusion of EWOM, enabled consumers to offer their consumption advices /42/. The internet provides much better opportunities for consumers to gather product information and advices from other consumers regarding consumption through EWOM, such as online reviews $/ 43 /$. EWOM is also known as an online rating or a description system that delivers credible and relevant product information to potential customers $/ \mathbf{4 4} /$, and has a significant impact on the final choice of consumer /45/. EWOM is a communication that is often anonymous and usually takes place between strangers /46/. Several types of EWOM are used to post and read content such as, online forums, blogs, social networking sites, and online consumer review sites /47/. Cheung \& Lee /48/ found that consumers' intention to participate in EWOM is linked to their ambition to increase their reputation. Online review is becoming an important means of marketing communication as many consumers search for it as the first step of an online purchase $/ 49 /$. According to one recent study, $93 \%$ of consumers said that reading online reviews significantly affects their purchase decision /50/. Online consumer reviews are personal messages regarding the consumer experience related to a product or service and are usually posted on the retail website, this information is accessible through a simple Google search /51/. Consumers tend to trust online reviews published by other consumers more than company reviews /52/. Consumers who participate in online reviews can be divided into those who post content (read and publish reviews on a regular basis), known as "Posters", and consumers known as "Lurkers" who do not participate in reviews, they only observe, and read reviews without posting /53/. These two categories can be defined as passive and active behavior. Therefore, these two types of review participants differ in their motivation to participate in EWOM. For the first category, motives are personal presentation and social concern, while the motives of others can be understood as information gathering /54/. According to $/ 55 /$, reviews from other consumers may be considered as a reliable source of information. EWOM content can take many forms and impacts. According to Vázquez et al. /56/, it can be positive or negative. Positive EWOM, as a free form of advertising, can help organizations by strengthening their brand or driving sales /57/. Hornik et al. /58/ claim that negative communication has a greater impact than positive. Negative EWOM can be characterized as a method of avenging behavior, usually it occurs in situations where consumers want to express their dissatisfaction by mocking the company or when they want to avoid interaction with the company $/ 59 /$. When a potential consumer seeks information and read a negative review, it leads to mistrust of the brand and negative attitude /60/. Henning et al. /61/ stated that negative reviews have the effect of discouraging potential consumers who have looked at the messages on the website, thereby reducing their sales potential in the future. According to 
Bechwati \& Morrin /62/, the desire for revenge can be characterized as the consumer's need to punish the company through online messages complaining that he or she has been harmed. The desire to avoid company is related to the need of consumers to no longer have any relationship with that organization, which may lead them to seek out the products or services of competing companies /63/. The negative EWOM shared by one dissatisfied consumer on the internet, has the potential to reach thousands of potential consumers. One study found that consumer complaints, behavior, or the willingness of consumers to engage in a negative EWOM can negatively affect a company's reputation $/ 64 /$.

\section{Micro and macro influencers on social media}

According to Uzunoğlu \& Kip /65/, social media influencers through their images, recommendations, or other content, can shape attitudes, opinions and actions of consumers and influence their final purchase decisions. According to Djafarova \& Rushworth /66/, digital influencers, such as celebrities, active members of online communities, bloggers (or video bloggers), use digital media channels to support brands, products or services, and to drive consumer purchasing decisions. Along with digital development, new technologies have created an opportunity for Social Media influencers to take over marketing space from brands through electronic word-of-mouth communication /67/. Influencers work on many types of social media, sometimes simultaneously on several different platforms, such as Instagram, YouTube, or Twitter. Two types of bloggers are distinguished: professional and commercial bloggers /68/. Marwick /69/ describes micro-influencers as ordinary people engaging in celebrity culture to increase their popularity online by using tools on the internet. They do this by planning and strategically sharing information aimed at building a specific relationship with their followers. According to Abidin /70/, micro-influencers create the impression of intimacy in communication, using various techniques such as posting photos that are not in high resolution, asking their ISSN 1330-0067 followers to comment their posts to enhance the content, and thus showing that they are similar to ordinary people. Veirman et al. /71/ define Influencer marketing as identifying social influencers and encouraging them to promote or support a brand (or product) on social media platforms. Cho, Hwang \& Lee /72/ noted that influencers on social networks play the role of digital opinion leaders. Influencers are perceived as members of online communities with the ability to influence and shape other members opinion with their expertise on a relevant topic. With the development and professionalization of online influencer marketing, companies began to design promotional posts for their influencers as an effort to control messages. Marketing departments share detailed instructions to their influencers about timings and which hashtags to use when publishing their posts. It is very common practice for companies to formulate a promotional post for their influencers from word to word /73/. According to Cheung \& Thadani $/ 74 /$, marketing information can be promoted faster and more efficient with the help of influencer recommendations to their followers. Pedroni /75/ points out that influencers function as micro-celebrities with a desire to achieve visibility and attention, therefore, influence others by their high social status and admiration for others. Hung \& /76/ noted that influencers often post content that is useful and knowledge-driven. Evans et al. /77/ argue that advertising with social influencers is significantly cheaper than other advertising methods. According to Mendoza /78/, marketers have started using bloggers to support their brands, because they can often be perceived as more credible sources of information than celebrities. Farooq \& Ja /79/ added that another advantage of this type of marketing is that influencers ensure consumer confidence in products, which is very important in today's competitive market. Trust in social media personalities comes from the perception that spontaneity and face-to-face conversations about brands are more credible than advertising campaigns. These interactions are considered sincere, because social media offers the ability to communicate worldwide without the involvement of companies. One of Coden: IORME7 
the main sources of influence are social circles, going beyond personal preferences and marketing messages, indicating that consumers tend to follow and imitate their peers /80/. One of the favorite strategies, often used in social media marketing is an endorsement or recommendation from celebrities (macro-influencers), as celebrities can help in generating attention and make an advertising message or campaign more appealing to the consumers /81/. A celebrity such as an entertainer, actor, or athlete is an eminent personality known in the society for their accomplishments /82/. McCracken /83/ defines celebrity as a publicly known person who uses his/her position to promote a product or brand in an advertisement. He added, that using celebrities by marketers can be very effective in a market with intense competition and it can provide differentiation. Solomon /84/ stated that celebrity endorsement is widespread today, over $20 \%$ of ads in the United States featuring celebrities. Celebrities are considered effective marketing tools because of their ability to attract consumer attention, which often can lead to increased awareness of the product or brand /85/. Support in brand identification in global markets is another benefit of this strategy. Generally, people get a better impression of a message that is recommended by a celebrity, thanks to that person's credibility. Celebrities, through their ability to attract consumer interest, can shape the brand as well as the image of the company $/ 86 /$. Followers, who are devoted to any celebrity, are influenced by him/her. According to Kalman's theory of identification, in order to create a self-defining relationship with another person, an individual attempt to take that person's attitude, behavior, or belief. When trying to impress the celebrity, followers (fans) often adopt his/her lifestyle and values $/ 87 /$. Followers usually strive to be like celebrities by imitating them in terms of quality, such as nice wardrobe, prosperity and fame /88/. Many studies have shown that there is a one-sided para social bond between followers (fans) and their favorite celebrities. As a significant number of celebrities actively engage with the social media platform, fans enjoy to follow content updates on their social media accounts and, also to discuss with people of similar interests. As a result, the mental and psychological boundaries between followers and celebrities will be narrowed, allowing fans to adopt a celebrity view /89/. Chan et al. /90/ argue that the use of celebrities in marketing communication can lead to greater trust and buying intentions, therefore, can increase product sales and improve the valuation of company shares.

The credibility of influencers recommendations on social media

Recommendations and EWOM are built on trust and credibility /91/. According to Hass /92/, source credibility defines if a person identifies as true, unbiased and factual. According to one study, $49 \%$ of users surveyed said they rely on recommendations of influencers on social media, while $56 \%$ of users said they rely on recommendations from friends $/ 93 /$. The trust towards the Social Media Influencers (SMI) increases, when consumers identify with them, therefore the consumer is more likely to buy (often impulsively) the product recommended by SMI /94/. When consumer connects to Social Media Influencer, it is more likely, he/she will adopt the product recommended by that person. Even in the cases when that product is not actually needed. Abidin /95/ noted that recommendations from Social Media Influencers provide consumers with a sense of inclusivity and authenticity.

The SMI recommendations about products are often considered more trustworthy and could increase the effort of consumers to make a purchase, in cases when consumer shares the preferences of products and the same personal interests like the influencer. If consumer chose to follow the recommendations from the SMI, it could, also indicate the fact that consumer and the SMI share the same personal interests /96/. If SMI is perceived as an expert in the area of content, chance at influencing a consumer to adopt the recommendation is much higher $/ \mathbf{9 8} /$. According to Nejad et al. /99/, the trust is influencing the level of how much consumers will believe in the information, about a recommended product, shared by an SMI. In 
some cases, SMIs would share with consumers a dishonest opinion. This occurs in situations where SMI is trying to build its career through collaboration with companies, that are often willing to pay for SMI services. If the trust is not built towards an SMI, the consumer will not believe in the information provided in the content. If SMI recommends products they do not use themselves, consumers can easily identify whose opinions and recommendations are not honest.

Credibility is one of the most important factors influencing people to adopt EWOM /100/. O'Keefe /101/ defined credibility as judgment concerning the believability of a communicator, that is made by a perceiver. Wathen and Burkell /102/ argue that one of the criteria using to filter unbelievable information is a credibility. Hass /103/ noted that the credibility of the source defines whether a person identifies a claim as true, unbiased and factual. Influencers "who are perceived to be attractive are more likely to lead the purchase intent" /104/. According to Lee \& Koo /105/ if the consumer perceives recommendations as not authentic and biased, in that case the level of credibility decreases. For the micro-celebrities and bloggers credibility is a key factor as it nurtures their effectiveness and may enhance their own media image /106/. Perceived trustworthiness and credibility are two of the features making the influencers very effective brand promoters /107/. Chu and Kamal /108/ link effectiveness and credibility, meaning that influencers want to be more effective in selling a product, they should be perceived as credible. According to Awad and Ragowsky /109/ the credibility information is the main determinant, for consumers, in the decisionmaking process. Information from a credible source, through a process known as "internalization" can influence opinions, believes, behaviors and attitudes. This process occurs when receivers accept the influence of sources in terms of their personal attitude and value structures /110/. Influencers "who are perceived to be attractive are more likely to lead the purchase intent" /111/. According to Ohanian /112/ the perceived credibility of an ISSN 1330-0067 influencer is measured in three dimensions: perceived attractiveness of influencers, trustworthiness and expertise. According to Van der Waldt et al., /113/ expertise can be defined as "the degree to which the endorser is perceived to have the adequate knowledge, experience or skills to promote the product". The expertise of the endorser is important only if consumers perceive it to be so /114/.

\section{Conclusion}

The aim of this paper is to present the results of the research aimed at establishing the correlation between credibility of influencer recommendations in the digital environment, primarily on social networks, and the changes that these recommendations may have on consumers perception towards brands and the consequences of these influences on their purchasing decisions. The first hypothesis confirmed the starting point that the consumers who are searching for the brand recommendation, have a tendency to trust more EWOM than WOM. The second hypothesis is also confirmed on the basis of the research results that showed that there is a statistically significant correlation between the attitudes of the respondents to the fact that consumers who are searching for online recommendation, when seeking for information about brands, will perceive Macroinfluencers as more credible sources than $\mathrm{Mi}$ cro-influencers. Testing of the third hypothesis also showed that there is a statistically significant correlation between the attitudes of respondents that when consumers are seeking for online information, and read a negative review, that can cause a negative attitude toward the brand, and reduce the sales potential in the future. The paper indicates that consumers trust electronic word-of-mouth communication more than traditional word-of-mouth communication, when looking for brand recommendations online. Also, in the process, they tend to trust macro influencers more than micro influencers. Finally, if they read information that is negative (in the form of a review), such information will have a negative impact on creating a negative attitude towards the brand and may reduce the purchasing potential in the future.

Coden: IORME7 
Notes

/1/ Sapountzi, A., Psannis, K.E. (2018). Social networking data analysis tools \& challenges. Future Gener. Comput. Syst., 86, 893-913.

/2/ Scissons, M., Vo, J. \& Sim, H. (2015). Instagram Marketing Strategy e-Book. Toronto: FlashStock Technology Inc.

/3/ Alexandrov, A., Lilly, B. \& Babakus, E. (2013). The effects of social- and self-motives on the intentions to share positive and negative word of mouth, Journal of the Academy of Marketing Science, vol. 41, 531-546.

/4/ Weiss, R. (2014). Influencer marketing. How word-of-mouth marketing can strengthen your organization's brand. Marketing Health Services, 34(1), 16-17.

/5/ Kim, S., Kandampully, J., \& Bilgihan, A. (2018). The influence of eWOM communications: An application of online social network framework. Computers in Human Behavior, 80, 243-254. https://doi.10.1016/j.chb.2017.11.015

/6/ Park, C. \& Lee, T.M. (2009). “Information direction, website reputation and eWOM effect: A moderating role of product type", Journal of Business Research, 62(1), 61-67.

/7/ Gungor, A. S. \& Cadirci, T.O. (2013). Segmenting eWOM engagers on online social networks based on personal characteristics and behaviour. Ekev Academic Review, 17(57), 33

/8/ Hornik, J., Satchi, R.S., Cesareo, L. \& Pastore, A. (2015). Information dissemination via electronic word-ofmouth: Good news travels fast, bad news travels faster! Computers in Human Behavior, 45, 273-280. doi: 10.1016/j.chb.2014.11.008

19/ Hennig, T.T., Gwinner, K.P., Walsh, G. \& Gremler, D.D. (2004). Electronic word-of-mouth via consumer-opinion platforms: what motivates consumers to articulate themselves on the internet?, Journal of interactive marketing, 18(1), 3852.

/10/ Uzunoğlu, E., \& Kip, S. M. (2014). Brand communication through digital influencers: Leveraging blogger engagement. International Journal of Information Management, 34, 592-602.

/11/ Langner, S., Hennigs, N. \& Wiedmann, K. (2013). Social persuasion: targeting social identities through social influencers, Journal Of Consumer Marketing, 30(1), 31-49. http://dx.doi.org/10.1108/07363761311290821

/12/ Kim, S., Kandampully, J., \& Bilgihan, A. (2018). The influence of eWOM communications: An application of online social network framework.
Computers in Human Behavior, 80, 243-254.

https://doi.10.1016/j.chb.2017.11.015

/13/ Van der Waldt, D., Van Loggerenberg, M., Wehmeyer, L. (2009), Celebrity Endorsements versus Created Spokespersons in Advertising: A Survey among Students. SAJEMS, 12(1), p.p. 104

/14/ Lee, K., \& Koo, D. (2012). Effects of attribute and valence of e-WOM on message adoption: Moderating roles of subjective knowledge and regulatory focus. Computers in Human Behavior, 28(5),

1974-1984.

https://doi.org/10.1016/j.chb.2012.05.018

/15/ Nielsen, M.I.S.W. (2017). Computer-mediated communication and self-awareness - A selective review. Comput. Hum. Behav. 76, 554-560.

/16/ Kapoor, K. K., Tamilmani, K., Rana, N. P., Patil, P., Dwivedi, Y. K., \& Nerur, S. (2017). Advances in Social Media Research: Past, Present and Future. Information Systems Frontiers, 1-28.

/17/ Carr, C. T., \& Hayes, R. A. (2015). Social media: Defining, developing, and divining. Atlantic Journal of Communication, 23, 46-65, p. 49

/18/ Akar, E. (2010). Sosyal Medya Pazarlamas1, Ankara: Efil Publications. P. 17

/19/ Russell, B.S.; Maksut, J.L.; Lincoln, C.R.; Leland, A.J. (2016). Computer-mediated parenting education: Digital family service provision. Child. Youth Serv. Rev. 62, 1-8.

/20/ Lee, A.R.; Suzanne Horsley, J. (2017). The role of social media on positive youth development: An analysis of 4-H Facebook page and 4-H'ers' positive development. Child. Youth Serv. Rev. 77, 127-138.

/21/ Ellison, N.B. \& Boyd, D. (2013). Sociality through social network sites. In: Dutton, W.H., ed. The Oxford Handbook of Internet Studies. Oxford: Oxford University Press. p 151-172.

/22/ Mangold W.G. \& Faulds, D.G. (2009). Social Media: The new hybrid element of the promotion mix, Business Horizons, 52(4), 357-365.

/23/ Wright, E., Khanfar, M.\& Kizer, L.E. (2010). The lasting effects of social media trends on advertising. Journal of Business $\mathcal{E}$ Economics Research, 8(11), 73-80.

/24/ Kotler, P. \& Keller, K.L. (2012). Marketing Management 14/e. Prentice Hall: Pearson.

/25/ Granata, G. (2016). Business Communication 2.0. Principi, evoluzione e strumenti della comunicazione d'impresa. Roma: Aracne editor.

/26/ Hennig, T.T., Gwinner, K.P., Walsh, G. \& Gremler, D.D. (2004). Electronic word-of-mouth via consumer-opinion platforms: what motivates consumers to articulate themselves on the internet?, Journal of interactive marketing, 18(1), 3852.

Coden: IORME7 
Piotr Kwiatek, Radoslav Baltezarević, Stavros Papakonstantinidis: THE IMPACT OF CREDIBILITY OF INFLUENCERS RECOMMENDATIONS ON SOCIAL MEDIA ON CONSUMERS BEHAVIOR TOWARDS BRANDS Informatol. 54, 2021., 3-4

193

/27/ Westbrook, R.A. (1987). Product/consumptionbased affective responses and post purchase Processes, Journal of Marketing Research, vol. 24, 258-270.

/28/ Emanuel, R. (2001). The anatomy of buzz: How to create word-of-mouth marketing. NewYork: Doubleday

/29/ Ennew, C.T., Ashish, K.B. \& Derek, L. (2000). "Managing Word of Mouth Communication: Empirical Evidence From India", International Journal of Bank Marketing, Vol. 18, No. 2, 75-83.

/30/ Yang, S., Mantian, H., Russell, S.W., Henry, A. \& Xiaohong, C. (2012),. "An Empirical Study of Word-of-Mouth Generation and Consumption", Marketing Science, Vol. 31, No.6, 952-963.

/31/ Katz, E. \& Lazarsfeld, B.F. (1955). Personal influence. Glencoe, Illinois: Free Press.

/32/ Garnefeld, I., Helm, S. \& Eggert, A. (2010), “Walk Your Talk: An Experimental Investigation of the Relationship Between Word of Mouth and Communicators' Loyalty", Journal of Service Research, Vol. 14, No. 93, 93-107.

/33/ Goyette, I., Ricard, L., Bergeron, J., and Marticotte, F. (2010). 'e-WOM Scale: Word-ofMouth Measurement Scale for e-Services Context', Canadian Journal of Administrative Science, 27 (1):523.

134/ Eagly A.H. \& Chaiken S. (1993). The Psychology Of Attitudes. Orlando: Harcourt Brace Jovanovich College Publishers.

/35/ Sundaram, D.S., Mitra, K. \& Webster, C. (1998). Word-of-mouth communications: A motivational analysis. Advances in Consumer Research, 25, 527531.

/36/ Assael, H. (2004). Consumer Behaviour: A Strategic Approach. Boston, MA: Houghton Mifflin

/37/ Day G.S. (1971). Attitude, change, media and word of mouth, Journal of advertising research, 6(11), 31-40.

/38/ Morin, S.P. (1983). Influentials advising their friends to sell lots of high-tech gadgetry, Wall street journal, Vol. 28, 30.

/39/ Hennig, T.T., Gwinner, K.P., Walsh, G. \& Gremler, D.D. (2004). Electronic word-of-mouth via consumer-opinion platforms: what motivates consumers to articulate themselves on the internet?, Journal of interactive marketing, 18(1), 3852.

/40/ Stephen, W.L. \& Ronald E.G.B. (2008). Electronic word-of-mouth in hospitality and 39 tourism management, Journal of Tourism Management, 29, 458-468.

/41/ Litvin, Goldsmith, \& Pan. (2008). Electronic word-of-mouth in hospitality and tourism management. Tourism Management, 29(3), 458-468. https://doi.org/10.1016/j.tourman.2007.05.011

/42/ Hennig, T.T., Gwinner, K.P., Walsh, G. \& Gremler, D.D. (2004). Electronic word-of-mouth via consumer-opinion platforms: what motivates consumers to articulate themselves on the internet?, Journal of interactive marketing, 18(1), 3852.

/43/ Ibidem

/44/ Bickart, B. \& Schindler, R.M. (2002). “Internet forums as influential sources of consumer information", Journal of Interactive Marketing, 15(3), 31-40

/45/ Yang, Y. \& Chou, M.J. (2000). “Effect of word-ofmouth communication on Consumer's Attitide Change", The Korean Journal of Advertising, 11, 734.)

/46/ Lee, M. \& Youn, S. (2009). Electronic word of mouth (eWOM), International Journal of Advertising, 28(3), 473-499.

/47/ Kotler, P. \& Keller, K.L. (2012). Marketing Management 14/e. Prentice Hall: Pearson.

/48/ Cheung, C.M.K. \& Lee, M.K.O. (2012). What drives consumers to spread electronic word of mouth in online consumer-opinion platforms, Decision Support Systems, vol. 53,. 218-225.

/49/ Park, C. \& Lee, T.M. (2009). "Information direction, website reputation and eWOM effect: A moderating role of product type", Journal of Business Research, 62(1), 61-67.

/50/ Tata, S.V., Prashar, S. \& Gupta, S. (2019). An examination of the role of review valence and review source in varying consumption contexts on purchase decision, Journal of Retailing and Consumer Services.https://doi.org/10.1016/i.jretconser.2019.01 .003

/51/ Kotler, P. \& Keller, K.L. (2012). Marketing Management 14/e. Prentice Hall: Pearson.

152/ Cheong, H.J. \& Morrison, M.A. (2011). Consumers Reliance on Product Information and Recommendations Found in UGC. Journal of Interactive Advertising, 8(2), 38-49. DOI: 10.1080/15252019.2008.10722141.

/53/ Hsu, Chin-Lung \& Lin, Judy Chuan-Chuan (2008). Acceptance of blog usage: The roles of technology acceptance, social influence and knowledge sharing motivation, Information $\mathcal{E}$ Management, 45(1):65-74.

/54/ Bartikowski, B. \& Walsh, G. (2014). Attitude contagion in consumer opinion platforms: posters and lurkers. Institute of Information management, 24, pp. 207-217. DOI: 10.100/s12525-013-0149-z.

/55/ Benwell, B. \& Stokoe, E. (2007). Discourse and Identity. Edinburgh: Edinburgh University Press. 
/56/ Vázquez-Casielles, R., Suárez-Álvarez, L. \& Del Río-Lanza, B. (2013). The word of mouth dynamic: How positive (and negative) WOM drives purchase probability, Journal of Advertising Research, 53(1), 43-60.

/57/ Gungor, A. S. \& Cadirci, T.O. (2013). Segmenting eWOM engagers on online social networks based on personal characteristics and behaviour. Ekev Academic Review, 17(57), 33

/58/ Hornik, J., Satchi, R.S., Cesareo, L. \& Pastore, A. (2015). Information dissemination via electronic word-ofmouth: Good news travels fast, bad news travels faster! Computers in Human Behavior, 45, 273-280. doi: 10.1016/j.chb.2014.11.008

/59/ McCullough, M.E., Bellah, C.G., Kilpatrick, S.D. \& Johnson, J.L. (2001). Vengefulness: Relationships with Forgiveness, Rumination, Well-Being, and the Big Five, Personality and Social Psychology Bulletin, 601-610.

/60/ Wang, L. (2010). The individual disposition to trust as a moderator of the relationship between electronic words-of-mouth and consumer brand attitude. Proceedings of the $5^{\text {th }}$ International Conference on Cooperation and Promotion of Information Resources in Science and Technology, 700-704.

/61/ Hennig, T.T., Gwinner, K.P., Walsh, G. \& Gremler, D.D. (2004). Electronic word-of-mouth via consumer-opinion platforms: what motivates consumers to articulate themselves on the internet?, Journal of interactive marketing, 18(1), 3852.

/62/ Bechwati, N.N. \& Morrin, M. (2003). Outraged Consumers: Getting Even at the Expense of Getting a Good Deal, Journal of Consumer Psychology, 13 (4), 440-53.

/63/ McCullough, M.E., Bellah, C.G., Kilpatrick, S.D. \& Johnson, J.L. (2001). Vengefulness: Relationships with Forgiveness, Rumination, Well-Being, and the Big Five, Personality and Social Psychology Bulletin, 601-610.

164/ Holloway, B.B. \& Beatty, S.E. (2003). Service failure in online retailing a recovery opportunity, Journal of Service Research, 6(1): 92-105.

/65/ Uzunoğlu, E., \& Kip, S. M. (2014). Brand communication through digital influencers: Leveraging blogger engagement. International Journal of Information Management, 34, 592-602.

/66/ Djafarova, E. \& Rushworth, C. (2017). Exploring the credibility of online celebrities' Instagram profiles in influencing the purchase decisions of young female users, Computers in Human Behaviour, $68,1-7$.

/67/ Zangeneha, S.K., Mohammadkazemib, R. \& Rezvanib, M. (2014). Investigating the effect of ISSN 1330-0067 electronic word of mouth on customer's purchase intention of digital products, Management Science Letters, 4(11), 2433-2440.

168/ Abidin, C. (2016). Aren't These Just Young, Rich Women Doing Vain Things Online? Influencer Selfies as Subversive Frivolity, Social Media + Society, Vol 2, Issue 2, 1-17.

/69/ Marwick, A. (2016). You may know me from YouTube: (Micro-) Celebrity in social media. In Marshall, P.D., \& Redmond, S. (Eds.), A Companion to Celebrity (333-350). West Sussex, UK: John Wiley \& Sons, Inc.

/70/ Abidin, C. (2015). Communicative intimacies: Influencers and perceived interconnectedness, Ada: A Journal of Gender, New Media \& Technology, 8. doi: 10.7264/N3MW2FFG.

/71/ Veirman M.D., Veroline C. \& Liselot H. (2017). Marketing through Instagram influencers: the impact of number of followers and product divergence on brand attitude, International Journal of Advertising, 36:5, 798-828, DOI: 10.1080/02650487.2017.1348035

/72/ Cho, Y., Hwang, J., \& Lee, D. (2012). Identification of effective opinion leaders in the diffusion of technological innovation: A social network approach, Technological Forecasting And Social Change, 79(1), 97-106. http://dx.doi.org/10.1016/j.techfore.2011.06.003

/73/ Abidin, C. \& Ots, M. (2015). The influencer's dilemma: the shaping of new brand professions between credibility and commerce. In AEJMC 2015, annual conference.

/74/ Cheung, C.M.K., Thadani, D.R. (2012). The impact of electronic word-of-mouth communication: A literature analysis and integrative model, Decision Support Systems, 54(1), 461-470.

/75/ Pedroni, M. (2016). Meso-celebrities, fashion and the media: How digital influencers struggle for visibility, Film, Fashion \& Consumption, 5(1), 103121. http://dx.doi.org/10.1386/ffc.5.1.103 1

/76/ Hung, C. \& Yeh, P.W. (2014). Identification of opinion leaders using text mining technique in virtual community. 1st Symp. on Information Management and Big Data, Cusco (Peru), 8-13.

/77/ Evans, N.J, Joe, .P, Jay, L. \& Hyoyeun, J. (2017). Disclosing Instagram Influencer Advertising: The Effects of Disclosure Language on Advertising Recognition, Attitudes, and Behavioral Intent, Journal of Interactive Advertising, 17 (2), 138-149. DOI: 10.1080/15252019.2017.1366885

/78/ Mendoza, M. (2010). I Blog. You Buy. How bloggers are creating a new generation of product endorsers, Journal of Digital Research and Publishing, 114-123.

Coden: IORME7 
Piotr Kwiatek, Radoslav Baltezarević, Stavros Papakonstantinidis: THE IMPACT OF CREDIBILITY OF INFLUENCERS RECOMMENDATIONS ON SOCIAL MEDIA ON CONSUMERS BEHAVIOR TOWARDS BRANDS Informatol. 54, 2021., 3-4

195

/79/ Farooq, F. \& Ja, Z. (2012). The Impact of Social Networking to Influence Marketing through Product Reviews, International Journal of Information and Communication Technolog,y Research Volume 2 No. 8, 627-637.

/80/ Kotler, P., Kartajaya, H. \& Setiawan, I. (2017). Marketing 4.0-Mudança do tradicional para o digital. Coimbra: Conjuntura Actual Editora.

/81/ Keel, A. \& Nataraajan, R. (2012). Celebrity endorsements and beyond: New avenues for celebrity branding, Psychology \& Marketing, 29(9), 690-703. doi:10.1002/mar.20555

/82/ Chia, S.C. \& Poo, Y.L. (2009). Media, celebrities, and fans: An examination of adolescents'media usage and involvement with entertainment celebrities. Journalism and Mass Communication Quarterly,86(1), 23-44. doi:10.1177/107769900908600103.

/83/ McCracken, G. (1989). Who is the Celebrity Endorser? Cultural Foundations of the Endorsement Process. Journal of Consumer Research, 16(3), 310-21.

/84/ Solomon, M. (2009). Real people, real choices. Toronto: Pearson Canada.

/85/ Chan, K., Leung Ng, Y. \& Luk, E. (2013). “Impact of celebrity endorsement in advertising on brand image among Chinese adolescents", Young Consumers, Vol. 14 No. 2, pp. 167-179. https://doi.org/10.1108/17473611311325564

/86/ Abdussalam, P.K. (2014). Celebrity advertisement: Key to marketing success, Indian Journal of Commerce and Management Studies, 5(1), 78-82.

/87/ Lindenberg, S., Joly, J.F. \& Stapel, D. A. (2011). The norm-activating power of celebrity: The dynamics of success and influence, Social Psychology Quarterly, 74(1), 98-120. doi:10.1177/ 0190272511398208

/88/ Chia, S.C. \& Poo, Y.L. (2009). Media, celebrities, and fans: An examination of adolescents'media usage and involvement with entertainment celebrities. Journalism and Mass Communication Quarterly,86(1), 23-44. doi:10.1177/107769900908600103.

/89/ Hung, K. (2014). Why celebrity sells: A dual entertainment path model of brand endorsement, Journal of Advertising, 43(2), 155- 166. doi:10.1080/00913367.2013.838720

/90/ Chan, K., Leung Ng, Y. \& Luk, E. (2013). “Impact of celebrity endorsement in advertising on brand image among Chinese adolescents", Young Consumers, Vol. 14 No. 2, pp. 167-179. https://doi.org/10.1108/17473611311325564
/91/ Kim, S., Kandampully, J., \& Bilgihan, A. (2018).

The influence of eWOM communications: An application of online social network framework. Computers in Human Behavior, 80, 243-254. https://doi.10.1016/j.chb.2017.11.015

192/ Hass, R. G. (1981). Effects of source characteristics on cognitive responses and persuasion. In Petty, R. E., Ostrom, T. M., \& Brock, T. C. (Eds.). Cognitive responses in persuasion (pp. 141-172). Hillsdale, NJ: Lawrence Erlbaum Associates.

193/ Swant, Marty. "Twitter Says Users Now Trust Influencers Nearly as Much as Their Friends." Adweek. Adweek, 10 May 2016. Web. $<$ http://www.adweek.com/news/technology/twitt er-says-users-now-trust-influencers-nearly-muchtheirfriends-171367. (Retrieved: 30/10/2019)

194/ Liu, S., Jiang, C., Lin, Z., Ding, Y., Duan, R., \& $\mathrm{Xu}, \mathrm{Z}$. (2015). Identifying effective influencers based on trust for electronic word-of-mouth marketing: A domain-aware approach. Information Sciences, 306, 34-52.

/95/ Abidin, C. (2015). Communicative intimacies: Influencers and perceived interconnectedness, Ada: A Journal of Gender, New Media E Technology, 8. doi: 10.7264/N3MW2FFG.

/96/ Liu, S., Jiang, C., Lin, Z., Ding, Y., Duan, R., \& $\mathrm{Xu}, \mathrm{Z}$. (2015). Identifying effective influencers based on trust for electronic word-of-mouth marketing: A domain-aware approach. Information Sciences, 306, 34-52.

/97/ Valck, K. d., Hoffman, D., Hennig-Thurau, \& Spann, M. (2013). Social Commerce: A Contingency Framework for Assessing Marketing Potential. Journal of Interactive Marketing, 27(3), 311-323.

198/ Assael, H. (2004). Consumer Behaviour: A Strategic Approach. Boston, MA: Houghton Mifflin

/99/ Nejad, M. G., Sherrell, D. L., \& Babakus, E. (2014, December 7). Influentials and Influence Mechanisms in New Product Diffusion: An Integrative Review. Journal of Marketing Theory and Practice, 22(2), 185-207.

/100/ Cheung, M., Luo, C., Sia, C., \& Chen, H. (2009). Credibility of Electronic Word-of-Mouth: Informational and Normative Determinants of On-line Consumer Recommendations. International Journal of Electronic Commerce, 13(4), 9-38. https://doi.10.2753/JEC1086-4415130402

/101/ O'Keefe, D. J., (1990). Persuasion: theory and research. Newbury Park: CA: Sage.

/102/ Wathen, C. N., and Burkell, J., (2002). Believe It or Not: Factors Influencing Credibility on The 
Web. Journal of the American Society for Information Science and Technology, 53(2), 134-144.

/103/ Hass, R. G. (1981). Effects of source characteristics on cognitive responses and persuasion. In Petty, R. E., Ostrom, T. M., \& Brock, T. C. (Eds.). Cognitive responses in persuasion (pp. 141-172). Hillsdale, NJ: Lawrence Erlbaum Associates.

/104/ Van der Waldt, D., Van Loggerenberg, M., Wehmeyer, L. (2009), Celebrity Endorsements versus Created Spokespersons in Advertising: A Survey among Students. SAJEMS, 12(1), p.p. 104

/105/ Lee, K., \& Koo, D. (2012). Effects of attribute and valence of e-WOM on message adoption: Moderating roles of subjective knowledge and regulatory focus. Computers in Human Behavior, 28(5),

1974-1984.

https://doi.org/10.1016/j.chb.2012.05.018

/106/ Chu, S.-C. \& Kamal, S. (2008). The Effect of

Perceived Blogger Credibility and Argument Quality on Message Elaboration and Brand Attitudes. Journal of Interactive Advertising, 8(2), 26-37. doi: 10.1080/15252019.2008.10722140

/107/ Ibidem

/108/ Ibidem
/109/ Awad, N.F. and Ragowsky, A. (2008)

“Establishing Trust in Electronic Commerce Through Online Word of Mouth: An Examination Across Genders", Journal of Management Information Systems, 24(4), pp. 101121.

/110/ Erdogan, B.Z. (1999). Celebrity Endorsement: A Literature Review. Journal of Marketing Management, 41(3), 291-314.

/111/ Van der Waldt, D., Van Loggerenberg, M., Wehmeyer, L. (2009), Celebrity Endorsements versus Created Spokespersons in Advertising: A Survey among Students. SAJEMS, 12(1), p.p. 104

/112/ Ohanian, R. (1990). Construction and validation of a scale to measure celebrity endorsers' perceived expertise, trustworthiness, and attractiveness. Journal of Advertising 19(3), 39-52.

/113/ Van der Waldt, D., Van Loggerenberg, M., Wehmeyer, L. (2009), Celebrity Endorsements versus Created Spokespersons in Advertising: A Survey among Students. SAJEMS, 12(1), p.p. 104 /114/ Erdogan, B.Z. (1999). Celebrity Endorsement: A Literature Review. Journal of Marketing Management, 41(3), 291-314. 